\title{
Training for general practice: a national survey
}

\author{
Helen S Crawley, Jonathan B Levin
}

\begin{abstract}
Objectives-(a) To compare current vocational training in general practice with that ascertained by a survey in 1980; (b) to compare the training of trainees in formal training schemes with that of trainees arranging their own hospital and general practice
\end{abstract} posts.

Design-National questionnaire survey of United Kingdom and armed services trainees who were in a training practice on 1 April 1989. Questionnaires were distributed by course organisers.

Setting-Research project set up after an ad hoc meeting of trainees at the 1988 national trainee conference.

Subjects -2132 of the 2281 trainees (93\%) known to be in a training practice on 1 April 1989.

Results-1657 Trainees returned the questionnaires, representing $73 \%$ of all trainees known to be in a training practice on 1 April 1989. Between 1980 and 1989 there were significant improvements in the trainee year, and there was also evidence of improvements in general practice study release courses. There was no evidence of improvement in other aspects of training. General practice trainees spent an average of three years in junior hospital posts, which provided very little opportunity for study related to general practice. Training received during tenure of hospital posts differed significantly between trainees in formal schemes and those arranging their own hospital posts. During the trainee year training was almost the same for those in formal schemes and those arranging their own posts. Regions varied significantly in virtually all aspects of general practice training.

Conclusions - The trainee year could be improved further by enforcing the guidelines of the Joint Committee on Postgraduate Training for General Practice. The poor training in junior hospital posts reflected the low priority that training is generally given during tenure of these posts. A higher proportion of general practice trainees should be attached to vocational training schemes. More hospital trainees could attend general practice study release courses if these were designed specifically with the needs of hospital doctors in mind.

RG4 7QH

Helen S Crawley, MRCGP, locum

Statistical Services Centre, Department of Applied Statistics, University of Reading, Reading RG6 2AN

Jonathan B Levin, MSC, statistician

Correspondence to: Dr Helen S Crawley, The Surgery, Loddon Hall Road, Twyford, Reading RG10 9JA.

Br.Med f 1990;300:911-5 formal schemes was compared with the experien trainees constructing their own schemes.

The results obtained were highly representative of the current state of general practice training. Replies were received from roughly $73 \%$ of all United Kingdom and armed services trainees who were in a training practice on 1 April 1989.

\section{Method}

Many of the questions in the survey were based on the 1980 national trainee conference questionnaire ${ }^{2}$ so that comparisons could be made. Drawing on the experience of the 1980 survey, ${ }^{2}$ we changed the methodology of the 1989 survey in two ways. Firstly, in 1989 only trainees actually in their trainee year were surveyed. Scheme and non-scheme trainees were therefore probably surveyed in their true proportions. In contrast, the 1980 survey attempted to reach all doctors who were training in general practice, both in hospital posts and in general practice posts. There were difficulties in distributing questionnaires, especially to hospital trainees who were not in organised training schemes. The 1980 survey did not distinguish between "do it yourself" trainees and trainees in organised schemes. It is probable that the results of the 1980 survey were biased by the inclusion of replies from hospital trainees, a disproportionate number of whom seem to have been in organised schemes.

The second difference in methodology was that in the 1989 survey individual coding of questionnaires allowed identification of a "follow up" group. The follow up group consisted of trainees who failed to return the first questionnaire that they were sent but replied to the second. No follow up group was identified in 1980.

Course organisers (that is, the people asked to distribute the questionnaires or their delegates-for example, postgraduate secretary or trainee representative) in the United Kingdom and armed forces were asked to distribute individually coded questionnaires to trainees who were in a training practice on 1 April 1989. The course organisers were also asked to complete decoding sheets stating which trainees had received which questionnaires. A total of 137 course organisers returned decoding sheets confirming that they had distributed 1633 questionnaires correctly. Fifty one course organisers did not return decoding sheets but when telephoned stated that they had correctly distributed 499 questionnaires. Eleven course organisers stated that their trainees had already received questionnaires from other course organisers. One course organiser stated that 19 trainees had declined to participate. Altogether 2132 questionnaires were distributed to trainees in their trainee year.

From the 135 decoding sheets returned by 1 July 1989 a follow up group of 510 trainees was identified. They consisted of trainees who had not replied by at least two weeks after other trainees on the same course. Returned questionnaires were accepted up to 1 August 1989. All decoding sheets were destroyed.

The questionnaire contained 59 questions. In statistical analyses $p=0.01$ was taken as significant $\left(\chi^{2}\right.$ test 
without continuity correction) owing to the large number of cross analyses performed. Except where stated otherwise results are presented as numbers and percentages of trainees who responded to a question. No question was answered by every respondent.

\section{Results}

In total 1657 useful replies were received, of which 184 were follow up questionnaires. There were roughly 2281 trainees in general practice on 1 April 1989 in the United Kingdom and armed services (Department of Health and advisers for general practice for the armed services and Northern Ireland, personal communications). The 2132 questionnaires distributed correctly therefore reached some $93 \%$ of trainees. The 1657 replies received represented roughly $73 \%$ of all trainees in the United Kingdom and armed services in a training practice on 1 April 1989.

There were only two significant differences between trainees who responded to the first questionnaire and those in the follow up group. The differences were in the use of role play at study release courses and whether trainees expected to undertake a project during their trainee year. The similarity between the initial and follow up groups suggested that the results presented below were fairly representative of the $93 \%$ of trainees who received a questionnaire. As in 1980 there was significant variation among the regions in virtually every aspect of training. ${ }^{2}$ (H S Crawley, unpublished data.)

TABLE I-Types of training preferred by trainees. Figures are numbers (percentages) of trainees who responded to both questions

\begin{tabular}{|c|c|c|c|c|}
\hline & \multicolumn{4}{|c|}{ Preferred type of training } \\
\hline & "Do it yourself" & $\begin{array}{l}\text { Scheme for } \\
\text { three years } \dagger\end{array}$ & $\begin{array}{l}\text { Scheme for less } \\
\text { than three yearsł }\end{array}$ & Other| \\
\hline $\begin{array}{l}\text { Actual training undertaken: } \\
\text { "Do it yourself" }(n=763) \\
\text { Scheme for three years } \dagger(n=614) \\
\text { Scheme for less than three years } \neq \\
\text { Other } \$(n=71)\end{array}$ & $\begin{array}{l}485(63 \cdot 6) \\
18(2 \cdot 9) \\
24(14 \cdot 3) \\
16(22 \cdot 5)\end{array}$ & $\begin{array}{r}211(27 \cdot 7) \\
574(93 \cdot 5) \\
57(33 \cdot 9) \\
27(38 \cdot 0)\end{array}$ & $\begin{array}{l}55(7 \cdot 2) \\
18(2 \cdot 9) \\
82(48 \cdot 8) \\
6(8 \cdot 5)\end{array}$ & $\begin{array}{l}12(1 \cdot 6) \\
4(0 \cdot 7) \\
5(3 \cdot 0) \\
22(31 \cdot 0)\end{array}$ \\
\hline
\end{tabular}

TABLE II - Average lengths of time trainees expected to spend in junior hospital posts

\begin{tabular}{|c|c|c|c|c|}
\hline & \multicolumn{4}{|c|}{ Type of training } \\
\hline & $\begin{array}{l}\text { Scheme for } \\
\text { three years } \dagger \\
(n=622)\end{array}$ & $\begin{array}{l}\text { Scheme for less } \\
\text { than three years } \neq \\
(n=167)\end{array}$ & $\begin{array}{c}\text { "Do it } \\
\text { yourself } \\
(n=746)\end{array}$ & $\begin{array}{l}\text { Other } \$ \\
(\mathrm{n}=64)\end{array}$ \\
\hline Length of time (years) & $2 \cdot 6$ & $2 \cdot 9$ & $3 \cdot 5$ & 3.9 \\
\hline
\end{tabular}

$\star+ \pm §$ See footnotes to table I.

TABLE III-Trainees' expectations about undertaking posts in obstetrics and paediatrics. Figures are numbers (percentages) of trainees who responded to both questions

\begin{tabular}{lcccc}
\hline & \multicolumn{5}{c}{ Type of training } \\
\cline { 2 - 5 } & $\begin{array}{c}\text { Scheme for } \\
\text { three yearst }\end{array}$ & $\begin{array}{c}\text { Scheme for less } \\
\text { than three years }\end{array}$ & $\begin{array}{c}\text { "Do it } \\
\text { yourself" }\end{array}$ & Other \\
\hline Do you expect to do obstetrics? & & & & \\
Yes & $600(95 \cdot 5)$ & $156(91 \cdot 2)$ & $651(85 \cdot 2)$ & $57(75 \cdot 0)$ \\
No & $27(4 \cdot 3)$ & $12(7 \cdot 0)$ & $83(10 \cdot 9)$ & $16(21 \cdot 1)$ \\
Don't know & $1(0 \cdot 2)$ & $3(1 \cdot 8)$ & $30(3 \cdot 9)$ & $3(3 \cdot 9)$ \\
Do you expect to do paediatrics? & $513(81 \cdot 7)$ & $122(71 \cdot 3)$ & $489(63 \cdot 8)$ & $37(48 \cdot 1)$ \\
Yes & $113(18 \cdot 0)$ & $38(22 \cdot 2)$ & $231(30 \cdot 2)$ & $37(48 \cdot 1)$ \\
No & $2(0 \cdot 3)$ & $11(6 \cdot 4$ & $46(6 \cdot 0)$ & $3(3 \cdot 9)$ \\
Don't know & & & & \\
Would you like to have had other hospital posts? & $341(55 \cdot 3)$ & $71(42 \cdot 3)$ & $281(37 \cdot 7)$ & $28(37 \cdot 3)$ \\
Yes & $254(41 \cdot 2)$ & $86(51 \cdot 2)$ & $414(55 \cdot 5)$ & $38(50 \cdot 7)$ \\
No & $22(3 \cdot 6)$ & $11(6 \cdot 5)$ & $51(6 \cdot 8)$ & $9(12 \cdot 0)$ \\
Don't know & & & & \\
\hline
\end{tabular}

*†‡See footnotes to table I.
TABLE: IV - Availability of study release course to hospital trainees. Figures are numbers (percentages) of trainees who gave definite response to both questions

\begin{tabular}{lcc}
\hline & $\begin{array}{c}\text { Was your most recent hospital post } \\
\text { part of an organised vocational scheme? }\end{array}$ \\
\cline { 2 - 3 } & $\begin{array}{c}\text { Yes } \\
(\mathrm{n}=661)\end{array}$ & $\begin{array}{c}\text { No } \\
\mathrm{n}=894)\end{array}$ \\
\hline Study release course available & $411(62 \cdot 2)$ & $186(20 \cdot 8)$ \\
Study release course not available & $250(37 \cdot 8)$ & $708(79 \cdot 2)$ \\
\hline
\end{tabular}

\section{TYPE OF TRAINING}

Table I shows a shortfall of places in three year vocational training schemes. Altogether 871 of 1620 $(54 \%)$ trainees would have preferred a three vear scheme but only 630 of $1652(38 \%)$ had undertaken such a scheme. Over a quarter of trainees who organised their own do it yourself scheme would have preferred an organised three year scheme.

\section{FEMALE TRAINEES AND PART TIME TRAINING}

The proportion of female trainees increased from $32 \%(532 / 1680)$ in 1980 to $46 \%(759 / 1655)$ in 1989 . There was no increase in the proportion of trainees undertaking part time training. Only $26(1 \cdot 6 \%)$ trainees were in part time posts in 1989.

\section{HOSPITAL TRAINING FOR GENERAL PRACTICE}

Length of training - Trainees expected to spend an average of just over three years in NHS hospital posts at senior house officer and registrar levels. The average length of time spent in hospital posts varied with the type of training (table II).

Unmet demand for hospital posts-Trainees were asked about the hospital posts that they expected to undertake and the posts that they wanted to obtain. A total of 1468 of $1643(89 \%)$ trainees expected to do an obstetrics job and $96(5 \cdot 8 \%)$ were unable to obtain a post despite wanting to. In paediatrics 1163 of 1646 $(71 \%)$ trainees expected to obtain a post and $234(14 \%)$ did not expect to obtain a post despite wanting to. Trainees in organised vocational training schemes were significantly more likely to obtain obstetric and paediatric posts than those arranging their own schemes (table III). Altogether 794 of $1610(49 \%)$ trainees stated that they would like to have had other hospital posts but could not. The posts that most trainees would like to have had, whether as a substantive post or as a short attachment, were in otorhinolaryngology (mentioned by 307 trainees), dermatology (287), ophthalmology (252), psychiatry (191), and general medicine (67). One hundred and thirteen trainees $(6 \cdot 8 \%)$ wanted short linked posts, most commonly in otorhinolaryngology, ophthalmology, and dermatology. Trainees in organised three year schemes were significantly more likely to have wanted these other hospital posts (table III).

\section{GENERAL PRACTICE TEACHING DURING TENURE OF} HOSPITAL POSTS

Trainees were questioned about their most recent postregistration hospital post. During their tenure of this post $664(42 \%)$ of the 1591 trainees who answered were part of an organised vocational training scheme.

Availability of general practice study release courseSix hundred of 1589 trainees $(38 \%)$ had a general practice study release course available to them during their most recent hospital post. Trainees not in a scheme were significantly less likely to have a study release course available or to be able to attend (tables IV and V). Block study release courses and evening or lunch time meetings were available to some trainees. These trainees were significantly more likely to attend than trainees whose general practice study was a half or full day release course. 
General practice oriented teaching by hospital staff-A total of $904(57 \%)$ of 1582 trainees received no general practice oriented teaching at all during tenure of their most recent hospital post. Trainees in an organised training scheme were no more likely to receive general practice oriented teaching than doctors whose posts were not part of an organised scheme.

Assessment during tenure of hospital posts-During their hospital jobs 1044 (67\%) of 1567 trainees did not have their progress regularly assessed; 188 (12\%) trainees did not know if they were assessed. Some trainees who were assessed commented that the assessment was not performed until the end of their hospital job or that the results were not shared with them. Trainees in organised training schemes were significantly more likely to be regularly assessed (table VI).

Attachment to a named general practitioner-Only 142 $(9 \cdot 1 \%)$ of 1552 trainees had the opportunity for attachment to a named general practitioner during their most recent hospital post. Almost a third of trainees $(464 ; 30 \%)$ wanted an attachment but did not have one.

\section{GENERAL PRACTICE STUDY RELEASE COURSE}

The use of all teaching methods surveyed in 1980 had increased in 1989 and trainees were more likely to

TABLE v-Percentage of study release course that trainees' hospital commitments allowed them to attend. Results refer only to trainees who stated that study release course was available. Figures are numbers (percentages) of trainees who gave definite response to both questions

\begin{tabular}{lcc}
\hline & \multicolumn{1}{c}{$\begin{array}{c}\text { Was your most recent hospital } \\
\text { post part of an organised } \\
\text { vocational scheme? }\end{array}$} \\
\cline { 2 - 3 } & $\begin{array}{c}\text { Yes } \\
(\mathbf{n}=402)\end{array}$ & $\begin{array}{c}\text { No } \\
(\mathbf{n}=161)\end{array}$ \\
\hline $\begin{array}{l}\text { Able to attend none of study release } \\
\text { course }\end{array}$ & $53(13 \cdot 2)$ & $53(32 \cdot 9)$ \\
$\begin{array}{l}\text { Able to attend } 1-49 \% \text { of study release } \\
\text { course }\end{array}$ & $119(29 \cdot 6)$ & $64(39 \cdot 8)$ \\
$\begin{array}{l}\text { Able to attend } 50-100 \% \text { of study release } \\
\text { course }\end{array}$ & $230(57 \cdot 2)$ & $44(27 \cdot 3)$ \\
\hline
\end{tabular}

TABLE VI-Regular assessment during tenure of hospital posts. Figures are numbers (percentages) of trainees who gave definite response to both questions

\begin{tabular}{lcc}
\hline & $\begin{array}{c}\text { Was your most recent hospital } \\
\text { post part of an organised } \\
\text { vocational scheme? }\end{array}$ \\
\cline { 2 - 3 } & $\begin{array}{c}\text { Yes } \\
(\mathrm{n}=578)\end{array}$ & $\begin{array}{c}\text { No } \\
(\mathrm{n}=796)\end{array}$ \\
\hline $\begin{array}{l}\text { Was your progress regularly assessed? } \\
\text { Yes } \\
\text { No }\end{array}$ & $189(32 \cdot 7)$ & $146(18 \cdot 3)$ \\
& $389(67 \cdot 3)$ & $650(81 \cdot 7)$ \\
\hline
\end{tabular}

TABLE VII-Evaluation of general practice study release courses in 1980 and 1989. Figures are numbers (percentages) of trainees who gave definite response

\begin{tabular}{|c|c|c|}
\hline & Yes & No \\
\hline \multicolumn{3}{|c|}{ Is your study release course alwavs or often worth attending? } \\
\hline $1980(n=1512)$ & $1038(69)$ & $474(31)$ \\
\hline $1989(n=1624)$ & $1243(77)$ & $381(23)$ \\
\hline \multicolumn{3}{|l|}{$\begin{array}{l}\text { Do trainees choose a quarter or more of the } \\
\text { subjects in your studv release programme? }\end{array}$} \\
\hline $1980(\mathrm{n}=1209)$ & $744(62)$ & $465(38)$ \\
\hline $1989(\mathrm{n}=1393)$ & $938(67)$ & $455(33)$ \\
\hline \multicolumn{3}{|c|}{ Do you use small group work teaching methods? } \\
\hline $1980(n=1454)$ & $1133(78)$ & $321(22)$ \\
\hline $1989(n=1602)$ & $1453(91)$ & $149(9)$ \\
\hline $\begin{array}{l}\text { Have you experience of meeting regularly in a } \\
\text { small group of doctors when the feelings or } \\
\text { behaviour of the members of the group were } \\
\text { discussed? }\end{array}$ & $\cdot$ & \\
\hline $1980(n=1589)$ & $790(50)$ & $79950)$ \\
\hline $1989(n=1622)$ & $1086(67)$ & $536(33)$ \\
\hline \multicolumn{3}{|l|}{ Do you use role play? } \\
\hline 1980 Not asked & - & - \\
\hline $1989(n=1566)$ & $975(62)$ & $591(38)$ \\
\hline \multicolumn{3}{|l|}{$\begin{array}{l}\text { Is there a residential course as part of your study } \\
\text { release programme? }\end{array}$} \\
\hline 1980 (Not asked) & - & - \\
\hline $1989(n=1554)$ & $847(55)$ & $707(45)$ \\
\hline
\end{tabular}

TABLE VII - Changes in trainee year since 1980. Figures are numbers (percentages) of trainees who gave definite response. Except where stated otherwise all increases and decreases compared with 1980 were significant

\begin{tabular}{|c|c|c|}
\hline & Yes & No \\
\hline \multicolumn{3}{|c|}{$\begin{array}{l}\text { Does your trainer give value for money for the } \\
\text { trainer's grant? }\end{array}$} \\
\hline $1980(n=1131)$ & $71663)$ & $415(37)$ \\
\hline $1989(n=1423)$ & $118183)$ & $242(17)$ \\
\hline \multicolumn{3}{|c|}{$\begin{array}{l}\text { Do you consider that you get enough teaching } \\
\text { from your trainer? }\end{array}$} \\
\hline $1980(n=1302)$ & $835(64)$ & $467(36)$ \\
\hline $1989(n=1531)$ & $1190(78)$ & $341(22)$ \\
\hline \multicolumn{3}{|c|}{$\begin{array}{l}\text { Is there an adequate library of books in trainee } \\
\text { practice? }\end{array}$} \\
\hline $1980(n=1311)$ & $647(49)$ & $664(51)$ \\
\hline $1989(\mathrm{n}=1617)$ & $1316(81)$ & $301 \quad 19)$ \\
\hline \multicolumn{3}{|c|}{ Are you ever left on call without back up cover? } \\
\hline $1980(n=1299)$ & $209(16)$ & $1090(84)$ \\
\hline $1989(n=1570)$ & $119(8)$ & $145192)$ \\
\hline \multicolumn{3}{|c|}{$\begin{array}{l}\text { Are you able to attend at least } 75 \% \text { of the study } \\
\text { release course? }\end{array}$} \\
\hline $1980(n=1282)$ & $1163(91)$ & $119(9)$ \\
\hline $1989(\mathrm{n}=1618)$ & $1551(96)$ & $67(4)$ \\
\hline \multicolumn{3}{|c|}{$\begin{array}{l}\text { Is your trainer a current member of the Royal } \\
\text { College of General Practitioners? }\end{array}$} \\
\hline $1980(\mathrm{n}=1240)$ & $850(69)$ & $390(31)$ \\
\hline $1989(n=1505)$ & $1127(75)$ & 378,25 \\
\hline \multicolumn{3}{|c|}{$\begin{array}{l}\text { Does your trainer regularly sit in on trainee } \\
\text { surgery? }\end{array}$} \\
\hline $1980(\mathrm{n}=1332)$ & $396(30)$ & $936(70)$ \\
\hline $1989(n=1598)$ & $583(36)$ & $1015(64)$ \\
\hline \multicolumn{3}{|c|}{$\begin{array}{l}\text { Is there regular discussion of video or tape } \\
\text { recorded consultations? }\end{array}$} \\
\hline $1980(n=1343)$ & $214(16)$ & $1129(84)$ \\
\hline $1989(n=1592)$ & $893(56)$ & $699(44)$ \\
\hline \multicolumn{3}{|c|}{ Is there regular random case analysis? } \\
\hline $1980(n=1327)$ & $784(59)$ & $543(41)$ \\
\hline $1989(n=1595)$ & $1130(71)$ & $465(29)$ \\
\hline \multicolumn{3}{|c|}{ Is there regular problem case analysis? } \\
\hline $1980(n=1327)$ & $1007(76)$ & $320(24)$ \\
\hline $1989(n=1615)$ & $1409(87)$ & $206(13)$ \\
\hline \multicolumn{3}{|c|}{ Are there regular tutorials on specific topics? } \\
\hline $1980(n=1342)$ & $930(69)$ & $412(31)$ \\
\hline $1989(n=1630)$ & $1503(92)$ & $127(8)$ \\
\hline \multicolumn{3}{|c|}{ Are you shown any clinical audit as a trainee? } \\
\hline $1980(n=1274)$ & $422(33)$ & $852(67)$ \\
\hline $1989(\mathrm{n}=1581)$ & $1006(64)$ & $575(36)$ \\
\hline \multicolumn{3}{|c|}{$\begin{array}{l}\text { Is your progress periodically assessed during } \\
\text { the trainee vear? }\end{array}$} \\
\hline $1980(n=1257)$ & $554(44)$ & $703(56)$ \\
\hline $1989(n=1417)$ & $1153(81)$ & $264(19)$ \\
\hline \multicolumn{3}{|c|}{ Do trainees regularly sit in on trainer surgery? } \\
\hline $1980(n=1350)$ & $865(64)$ & $485(36)$ \\
\hline $1989(n=1628)$ & $950(58)$ & $678(42)$ \\
\hline \multicolumn{3}{|c|}{ Are there regular joint home visits? } \\
\hline $1980(n=1353)$ & $785(58)$ & $568(42)$ \\
\hline $1080(n-1628)$ & $816(50)$ & $812(50)$ \\
\hline \multicolumn{3}{|c|}{ Does the trainee have his or her own room? } \\
\hline $1980(n=1355)$ & $690(51)$ & $665(49)$ \\
\hline $1989(n=1634)$ & $888(54)^{\star}$ & $746(46)^{\star}$ \\
\hline
\end{tabular}

find their study release course worth attending (table VII).

\section{TRAINEE YEAR}

Changes in trainee year since 1980-During the traineee year the only significant difference between trainees in a three year scheme and those arranging their own do it yourself schemes was in the use of problem case analysis. Table VIII shows the changes that occurred in the trainee year between 1980 and 1989. Identical questions were asked in the two years, and the probable overrepresentation of trainees in a formal scheme in 1980 was unlikely to have biased the results.

Amount of teaching-In 1980, 59 of 1348 trainees $(4 \cdot 4 \%)$ received no teaching from their trainers. In 1989 eight of $1607 \cdot(0 \cdot 5 \%)$ received no formal or informal teaching from their trainers. Thirty three of 1604 trainees $(2 \%)$ received no formal teaching from their trainer or any partner in their training practice in 1989. A rough estimate was made of the average weekly amount of teaching received by trainees. This included formal and informal teaching from the trainer and formal teaching from other partners. Trainees who were satisfied with the amount of teaching they received had, on average, 4.4 hours' teaching a week. Trainees who were dissatisfied received an average of $2 \cdot 2$ hours' teaching a week. 
Telephone answering - In 1989, 437 of 1627 trainees $(27 \%)$ were expected to provide somebody to answer the telephone out of hours, at least sometimes. For some trainees this was a source of conflict with their training practice. Fifty two $(12 \%)$ of the telephone answerers were paid by the practice. In 1980, 653 $(48 \%)$ of 1359 trainees were expected to provide someone to answer the telephone. We do not know how many were paid.

\section{Discussion}

FEMALE TRAINEES

In 1989 almost half of general practice trainees were women. This paralleled an increase in the proportion of female medical students from $35 \%$ in 1978 to $44 \%$ in 1987. In $1987,42 \%$ of female principals were under 30 . The Department of Health's 1990 statement of fees and allowances ${ }^{3}$ must be costed so that vocationally trained women are not compelled to accept unsatisfactory posts.

The proportion of trainees undertaking part time general practice training had not risen since 1980.2 Sixty one $(3 \cdot 7 \%)$ trainees wanted part time training and 10 trainees would have preferred "a choice." Only 26 trainees were undertaking part time training in 1989. In 1980 there was widespread confusion over the availability of part time training, ${ }^{2}$ which may explain some of the shortfall.

\section{HOSPITAL TRAINING}

Many trainees are unable to obtain all the hospital posts that they want, and most receive little or no relevant teaching or assessment during their tenure of these posts. The problems in the North Western region are national. ${ }^{13}$

\section{Hospital posts undertaken}

On average trainees spend three years in junior hospital posts in the NHS, one year more than is required for Joint Committee on Postgraduate Training for General Practice certification. ${ }^{+}$The government's policy statement on the balance of junior and senior hospital posts ${ }^{5}$ did not fully address the needs of general practice trainees.

A few trainees were unable to obtain the posts that they wanted in obstetrics and paediatrics, and this was consistent with the results of other surveys in which trainees were asked about all hospital posts undertaken. ${ }^{26}$ ? There had been no improvement since 1980. The shortfall was small, especially in obstetrics, and it should be possible to create some extra posts by improving duty rotas. Hospitals should not require vocational trainees to spend more than six months in a post. The shortfall in paediatric posts might be improved by providing more combined hospital and community paediatric posts.

Trainees in organised schemes were more likely to want to have undertaken other hospital posts which they could not do as part of their vocational training. Trainees were not asked whether they wished to spend longer in hospital to incorporate additional posts or whether they would have preferred a different combination of posts over the same period. It should be possible to offer some additional experience during a three year scheme by attendance at outpatient clinics or specific training during the trainee year.

\section{Training during tenure of hospital posts}

General practice study release programmes were poorly available and rarely attended. Fewer than half of the trainees received any general practice oriented teaching from the hospital staff whether or not they were part of a vocational training scheme. There was limited opportunity for attachment to a general practi- tioner and little assessment of trainees' progress.

Recent reports have suggested that junior hospital doctors should participate in organised and structured teaching. ${ }^{8}{ }^{811}$ Nevertheless, training in senior house officer posts remains poor. ${ }^{2}$ The inadequacies of hospital training for general practice reflect general deficiencies in junior hospital training. Hospital training for general practice, however, might be improved by three practical measures.

Firstly, the proportion of trainees who are able to obtain their preferred option of joining an organised training scheme might be increased. Trainees in vocational training schemes are more likely to attend general practice study release courses, to be attached to general practitioners, and to have regular assessments. Training for those who do not join an organised training scheme might be improved if they were nominally attached to the local vocational training scheme.

Secondly, more trainees should undertake an introductory period in general practice. A total of 339 (54\%) of 629 trainees in an organised three year scheme spent a period working as a trainee in general practice before their hospital posts. Only $33(4 \cdot 3 \%)$ of 765 do it yourself trainees had an introductory period. Trainees who had undertaken an introductory period were significantly more likely to consider that they had received general practice oriented teaching from hospital staff. This may be either because their previous general practice experience enabled them to direct any teaching that they received towards general practice or because they appreciated that teaching received was actually relevant. Trainees who had experienced an introductory period were also significantly more likely to think that an introductory period was useful. The mean length of introductory periods was 4.5 months and the mode six months. Trainees worked from two weeks to an exceptional 54 months in general practice before beginning their hospital training. The longest introductory periods were generally in the armed services. Several trainees whose introductory period had been six months or more commented that this was too long.

Thirdly, general practice study release courses should be set up with the needs of hospital trainees specifically in mind. Trainees were significantly more likely to be able to attend their general practice study release course if block study release courses or evening or lunch time meetings were available. Block study release courses were probably the best system for increasing the attendance of hospital trainees. We cannot say whether non-scheme trainees in the same hospitals were also able to benefit from these arrangements. Possibly course organisers could aim at providing "general practice appreciation courses" available to all junior doctors. Hospital trainees intending a career in general practice might use the study leave entitlement, which currently they rarely take. ${ }^{13}$

\section{TEACHING METHODS USED IN STUDY RELEASE COURSE}

Trainees seemed to be more satisfied with their study release courses in 1989 than they had been in 1980.' This may be because in 1989 more trainees were being taught through small group work and Balint type groups and were choosing a quarter or more of the subjects for study. These factors and role play (not surveyed in 1980) were highly significantly associated with satisfaction with the study release course. The availability of a residential course was not associated with trainee satisfaction.

\section{TRAINEE YEAR}

Although there had been significant improvements since 1980, many trainees still worked under poor conditions or received inadequate training. In 1989 more trainees believed that their trainer gave "value for 
money" for the trainer's grant. The amount of teaching received was the single most important factor in this belief.? Trainees who were satisfied with their teaching received an average of $4 \cdot 4$ hours' teaching a week, considerably less than the seven hours a week (two sessions) recommended by the Joint Committee on Postgraduate Training for General Practice. ${ }^{14}$

Teaching methods had changed since 1980 . Videos, audit, tutorials on specific topics, random and problem case analysis, and trainers sitting in on trainee surgeries were used more in 1989. Use of "apprenticeship" methods of training-trainees sitting in with their trainer and joint home visits - had decreased. Although this survey did not examine the issue of which teaching methods were most effective, comments received from trainees suggest that individual trainees have individual requirements. Trainers who are experienced and competent in the use of a wide variety of methods are likely to be able to arrive at the teaching which best suits their trainee.

Improvements in training are probably due to various factors. Much more has been published and discussed about training. More trainers have undergone full vocational training themselves. In 1985 the Joint Committee on Postgraduate Training for General Practice published guidelines for the approval of trainers. ${ }^{14}$ These are enforced through visits to the regions. The joint committee is prepared to sanction the withdrawal of approval of a whole region where criteria for the selection of trainers do not reach required standards.

There remains, however, considerable room for development and improvement of the trainee year. Enforcement of regional criteria for the approval of trainers would resolve some trainee problems. A periodic year without a trainee would prevent practices relying on the service commitment of trainees. Sensitive and effective channels of complaint should be available to trainees who think that their training is not suitable. Trainees should not feel that criticism of their training might result in bad references.

As the new statement of fees and allowances ${ }^{3}$ and the white paper Working for Patients ${ }^{15}$ start to take effect there may be changes in the resources devoted to vocational training for general practice. It is important that during this period of rapid change we should continue to monitor all aspects of general practice training.

We are grateful to the scientific foundation board of the Royal College of General Practitioners for a grant to cover expenses. Thanks are also due to all the course organisers and trainees who cooperated with the survey and to DrC Ronalds, Professor R Higgs, Dr B Clarke, S Barry, Dr S Ronay, Dr A Ruben, J C W Crawley, and Dr D Casey for advice and support.

1 Reissman G, Thomas M. The 12th national trainee conference, 1988. Horizon $1989 ; 3: 501-4$

2 Ronalds C, Douglas A, Gray DJP, Selly P, eds. Fourth national traine conference. London: Royal College of General Practitioners, 1981. Occasional paper 18

3 Department of Health and Social Security. Statement of fees and allowances pavable to general medical practitioners in England and Wales from $1 \mathrm{April} 1990$ pavable to general medical practitumers

+ Joint Committee on Postgraduate Training for General Practice. Selection of posts in hospital and community medicine for vocational training in general practice. London: JCPTCPP, 1980.

5 UK Health Departments, Joint Consultants Committec. Chairman of Regional Health Authorities. Hospital medical staffing-achieving a balance Plan for action. London: HMSO, 1987.

6 Polnay L, Pringle M. General practitioner training in paediatrics in the Tren region. Br.Med 7 1989;298:1434-6.

7 Carne S. What others do: Is vocational training for general practice working? Modern Medicine 1986 June:59-60.

8 General Medical Council Education Committee. Recommendations on the training of specialists. London: (iMC, 1987.

9 Council for Postgraduate Medical Education in England and Wales. The problems of the senior house officer. London: CP.ME, 1987.

10 Brearley S, Beuzart S, Gredal J, Suntinger A, Gentleman D. Permanent Working Group of European Junior Hospital Doctors. Policy statement on postgraduate medical education. Education 1989:23:339-47.

11 Council for Postgraduate Medical Education in England and Wales. A proposal for a district medical education structure. London: CPME, 1987.

12 Grant J, Marsden P. King R. Senior house officers and their training. I Personal characteristics and professional circumstances. II. Perceptions of service and training. Br.Med $\mathcal{F}$ 1989;299:1263-8.

13 Reeve B, Bowman A. Hospital training for general practice: views of trainees in the North Western region. Br Med F 1989;298: 1432-4.

14 Joint Committee on Postgraduate Training for (ieneral Practice. Recommendations to regions for the establishment of criteria for the approial and reapproval of trainers in yeneral practice. London: JCPTGP, 1985.

15 Secretaries of State for Health, Wales, Northern Ircland, and Scotland Working for patients. London: HMSO, 1989.

Accepted 9 Februar 1990

\section{ONE HUNDRED YEARS AGO}

We would fain hope that the long-delayed legislation for the benefit of the blind and deaf will soon be carried to a successful issue. The Conference on the Treatment of the Blind, held at the Society of Arts last November, following the Conference concerning the Deaf held in Manchester, prepared the way for the deputation to the Lord President of the Council (Lord Cranbrook) when the representatives of both those classes of sufferers brought forward their views, and urged upon the Government the necessity for giving effect at once to the recommendations of the Royal Commission.

Dr. Armitage, whose devotion to the welfare of the blind is so well known, brought forward a series of resolutions giving practical effect to the decisions of the Royal Commission; and, on the motion of Dr. Symes Thompson, Mr. B. St. John Ackers was desired to point out to Lord Cranbrook what were the main points required for the deaf

As regards the blind, inasmuch as the large majority become blind between the ages of 45 and 65 , the question of education has reference only to a small percentage of the whole number; but there can be no question that the provisions of the Education Act should be brought to bear on this small percentage; that the blind should have compulsory education, inspection, and grants for maintenance; and that this need in no way interfere with the flow of charity which has hitherto done so much.

As regards the deaf and dumb, for whom public benevolence has done comparatively little, there was an absolute unanimity of opinion that deaf children must be sought out and educated with at least as much assiduity as the hearing. They must be brought to school at the age of 7 or 8 , and kep there for at least seven years. Thus, if the teaching is efficient, the child would be in a position to enter into life with good hope of success. The educational grant must be at least the equivalent of that for the hearing Inasmuch as the successful teaching of the deaf requires very special skill, education, and experience, the salaries of the teachers should be good, and inducements should be held out to attract a high class of teachers.
Training colleges for teachers of the deaf, although they have already done good work, require Government aid and recognition. It was Lord Salisbury's Government that appointed the Roval Commission, and let us trust that his Government will obtain the credit of carrying into law the results of its labours.

The time has come for action, and we are giving expression to the earnest desire of the physicians and philanthropists when we say that we earnestly hope that the recommendations of the Royal Commission will be at once carried out. They are mainly these:-

That the provisions of the Education Acts be extended to the blind and deaf, and that power be obtained to enforce the attendance of deaf children at the institute or day-school from 7 up to the age of 16 .

That the school authority should be empowered to send children to institutions, or to board them out under proper inspection, and to contribute to their education and maintenance.

That technical instruction in industrial handicrafts be made a part of the curriculum in schools for the deaf.

That training colleges for teachers are of paramount importance, and that these colleges require Government assistance, examination, and inspection, like the training colleges for the hearing; two years' training being regarded as essential for the students.

That training in the anatomy and physiology of the organs of speech and hearing is a necessary preliminary, and that a duly qualified examiner should be appointed to inspect the institution.

It was gratifying to learn from Lord Cranbrook that he considered that the existing training colleges had done good work, and, with slight modifications, might be developed so as to fulfil every requirement.

All the propositions brought forward by the deputation appeared so important that we would fain hope that they will form part of any measure that may be introduced for the benefit of the blind and the deaf.

(British Medical fournal 1890;i:192) 